\title{
Islam and Democracy: A Critical Reappraisal of Adaptation and Contrast Theories
}

\author{
Khalil Sardarnia $^{1} \&$ Yalda Bahrampour ${ }^{2}$ \\ ${ }^{1}$ Political Sciences Department, Faculty of Law \& Political Sciences, Shiraz University, Shiraz, Iran \\ ${ }^{2}$ Ph.D. Candidate at Political Sciences, Science and Research Branch, Islamic Azad University, Tehran, Iran \\ Correspondence: Khalil Sardarnia, Political Sciences Department, Faculty of Law \& Political Sciences, Shiraz \\ University, Shiraz, Iran. E-mail: Kh_sardarnia@yahoo.com
}

Received: December 3, 2016

Accepted: January 24, 2017

Online Published: April 20, 2017

doi:10.5539/jpl.v10n3p1

URL: https://doi.org/10.5539/jpl.v10n3p1

\begin{abstract}
With the expansion of Islamism, a wave of Islam phobia was launched by western Orientalists and intensified subsequent to September 11 Attacks. Theoretically, the subject of adaptation and compatibility or contrast between Islam and democracy has drawn the attention of academic circles. Using a comparative and analytical research procedure, the current article seeks to provide an answer to this question: In the area of Adaptation and Contrast Theories, what is the nature of the relationship between Islam and democracy? The research's hypothesis is that: from Contrast perspective, adaptation between democracy and Islam is not possible due to ontological and epistemological differences. In contrast, given the existing rational and democratic potentials within the framework of genuine Islamic fundamentals, democratic empirical examples such as democratic attitudes and demands in Islam world and democratic governance in the Middle East countries and Islam world, adaptation oriented parties believe in the existence of contextualized democracy within the framework of Islam. Using a critical reappraisal, it must be noted that, in spite of some deficits, Adaptation is more tenable, while Contrast and Essentialism are not sufficiently tenable due to some causes including failure to make a distinction between Islam's basic fundamentals and history of Islam, the performance of authoritarian regimes and radical Islamists, universalization of liberal-secular democracy discourse and its combination with western ethnic chauvinism and propaganda of Islam phobia and defamation to Islam.
\end{abstract}

Keywords: Islam, democracy, adaptation, contrast

\section{Introduction}

From the late 1960s onwards, with the decline of nationalism and socialism, Islamism as a political ideology was promulgated quickly in the Arab world. However, due to the failure of nationalism and socialism, and the defeat of pan-Arab governments from Israel in 1967, as well as the failure of the regimes to realize the stated objectives for the Muslim Arab masses caused that political Islam become the dominant discourse among Muslim societies. Initially, under the guise of "resistance identity", Islamists sought to fight against right-wing secular authoritarian regimes which were dependent on the West. However, over time, it was became clear that they do not want to stay on a defensive stance forever. Therefore, they turned to a "program-based identity" to establish the Islamic state and to fulfill Islam's religious beliefs and doctrines, and its acme was serious participation in recent revolutions or social movements since 2011.

With the expansion of Islamism in the West on the one hand, an anti-Islam and "Islam phobia" wave was launched, which this responsive action was exacerbated especially after the September 11 Attacks. The origins of these types of reactions were mainly Western Orientalists, Contrast-oriented and essentialist thinkers such as Bernard Lewis, Elie Kedourie, Samuel Huntington, and Francis Fukuyama. By highlighting the practice of some extremists in Muslim countries, Western Medias and politicians sought to depict religion as a real threat against the Western civilization. At the heart of the Clash of Civilizations and contrast-orientation is the issue of Islam's inherent violence and its incompatibility with democracy. On the other hand, in the West and Islamic world, the subject of the relationship and compatibility between democracy and Islam, and also between Islam and violence theoretically were of special interest to scientific-academic circles.

In present article, the authors seek to examine the compatibility between Islam and democracy from the 
perspective of two theoretical approaches, namely adaptation and contrast essentialism. In addition, using a comparative, analytic, and referential approach, the authors intend to find an analytic answer to the following questions:

What is the relationship between Islam and democracy in terms of adaptation and contrast theories, and what would be the nature of the relationship? The research hypothesis is that, according to contrasts, due to substantive ontological and epistemological differences it is not possible to adapt democracy and Islam even in terms of their essence. However, with regard to the democratic and intellectual capacity available in the original Islamic principles, and also empirical democratic examples such as democratic demands and attitudes in the Muslim world, and presence of some instances of democratic governments in some Middle East countries and Islamic world, adaption-oriented parties believe in a contextualized democracy within the framework of Islam.

In terms of the research background and literature, it should be noted that a number of sources including the works by Esposito, Shirin Hunter, Mansour Mo'addel, Huntington, Bernard Lewis, etc. have addressed the same issue, although present study is not lengthy enough to discuss these works even briefly, and it should be noted that the views underlying such contributions have been outlined under two theoretical approaches. Investigate and analyze political Islam and its relationship with democracy is a necessity due to the following reasons: 1-The sparse nature of the literature on critical assessment of contrast approach and Clash of Civilizations and their major focus on mostly theoretical and less comparative/inferential analysis of the research subject. 2-The significance of the issues such as critical assessment of the Clash of Civilizations and contrast approach to deal with intellectual-political challenges academically, Iran-phobia and Islam phobia and the Western countries soft war against Islam, 3-The significant lack of attention paid to empirical quantitative studies in the form of the thesis and books on critical approach to the Clash of Civilizations. 4-The paucity of the resources and research performed with a comparative approach and the views held by leading theorists on the two approaches including Adaptation and contrast, and at the same time provide empirical instances and surveys conducted regarding compatibility between Islam and democracy.

\section{Adaptation Theory}

In Adaptation approach, the prevailing belief is that there is no conflict between Islam and democracy, thus Islam and democracy can coexist in same society. Go even further, some have emphasized that under the current circumstances, democracy is essential for the Muslim world. Thinkers and theorists in Adaptation approach believe that the majority of Islamists adopt democratic approaches compatible with Islam, and they tend to be cooperative, peaceful and democratic. According to them, by giving more authority to the Islamists, they can be pushed into accepting democracy (Haider, 1995: 43). Applying some expressions such as "Islamic Revivalism", "Islamic Renaissance", and "political Islam", adaptation-oriented parties advocate a "contextualized interpretation of democracy". On the one hand, they seek to recognize modernity, its necessities, and modern science teaching and learning, and on the other hand, they seek localized modernity and democracy as a government policy, adapting Islam and democracy, and apply principles such as Shoura (consultation) and Ijtihad (deducing conclusions through discretion). In this section, to better understand this approach, the views held by the recognized thinkers and proponents of this approach in the Arab-Islamic world and the West are outlined.

\subsection{The Approach of Religious Modernists in Arab-Islamic World}

"Religious modernism" was born in the 19th century to deal with conservative Salafist traditionalism mainstream. Seyed Jamal's intellectual teachings, which were based on adaptability between Islam and wisdom, science and technology, the necessity to reform public thinking and beliefs, to remove superstitions and develop unity in the Islamic world, were the starting point of modernization process in the Muslim world (Calvert, 2004: 35). In general, the main objective underlying this movement was presenting a modern understanding of Islam while showing faithfulness to the original principles of Islam and to show existing adaptability between Islam and science, democracy, rationality and modern technology, through relying on Ijtihad and modern interpretations of the Holy Quran (Calvert, 2004: 35). Seyed Jamal was a proponent of democracy as a government policy minus the secular liberalism ideology and from a contextualized point of view and compatible with Islam that its rules and decisions are not incompatible with Islam. Seyed Jamal advocated democratic mechanisms such as parliament, deliberative (consultative) decision making, elections, accountability of rulers to the people, and the adaptability of these mechanisms to Islamic mechanisms such as the Council and Ijtihad in Islam, etc. (Tamimi. 2007: 45).

In general, religious modernists or moderates took an intermarry status between radical Salafi fundamentalists and liberal Islamists, and are more accepted in Islamic world. In terms of the intellectual-ideological issues, 
moderate and modernist Islamists do not completely reject Salafis thoughts and advocate the necessity of obedience to the Qur'an, the Sunnah and Rashidun caliphs, and attempt to fulfill God's sovereignty. In contrast, in connection with the implementation of divine sovereignty, how to fight and take action, and attitudes towards democracy, science and rationality, moderate and modernist Islamists are seriously opposed to fundamentalist Salafist Extremists. Religious modernists seek to achieve understanding of Islam that is compatible with modernization, i.e. they believe in a modern and historical recognition of Islam and the Quran and four sources of law and jurisprudence including the Qur'an, Sunnah, Ijmae, and analogy (Qias). Concerning Ijmae and analogy, they mostly believe in rational, practical and modern standards relevant to social theory. They advocate adaptabity of Islam with formal democratic mechanisms such as free elections, the referendum, pluralism and the rule of the majority, and they defend from democratic principles and values such as freedom, the rule of law, leniency within the framework of the law and the principle of Ijtihad based on logical and rational interpretations Of religion and sacred texts, and they severely denounce violence. Concerning the relation between religion and reason, they believe in the originality of religion, beside that they respect wisdom and they use it in interpreting religion and the Quran as long as it does not challenge the structure and origin of the religion.

In recent decades, some theorists and thinkers such as Malek Bennabi, Hassan al-Hudaybi, Rached Ghannouchi, Nasr Hamid Abu Zayd, Mustafa Mashhur, Tariq Al-Bushra, Mohamed Emara, and Abdel-Wahab El-Messiri, and Munir Shafigh have entered religious modernism and political and intellectual struggle. Malek Bennabi Al Jazayeri is a leading thinker in North Africa and the Middle East's Religious Modernism Circle. Using a context-oriented and contextualized approach, he believes in the compatibility of Islam and democracy, and advocates creation of a logical combination between them to assist these communities to release from decadence. From Benabi's perspective, by adopting a postmodernist deconstructive approach to secular democracy and a re-defining it, it would be possible to realize applied and local democracy in the Muslim world (Tamimi. 2007: 53).

Tariq Ramadan (the grandson of Hassan al-Banna) is a recognized contemporary moderate religious modernist. Unlike most liberal Islamic thinkers, he does not seeks to relegate the law to a non-binding Code of Ethics, rather he believes in the new interpretations and re-interpretation of the law and Islamic law. On the one hand, he criticizes the liberals in the Middle East and North Africa who secularize the religion, surrender against West, and liberalism teachings. On the other hand, Tariq Ramadan criticizes traditionalist and fundamentalist Islamists because of their fanaticism and disbelief in Ijtihad and interpretation (tafsir). He encourages the adoption of Western law, provided localization and reverence to Islamic law and rights, and he is an opponent of traditional imperative Islamic monopoly at the same time (Hafez, 2010: .33).

Yusuf Qaradawi as the founder of the Islamist party "al-Wasat" is a moderate and modern Islamic thinker. Same as other modern thinkers, he insists on the reinterpretation of Islamic principles in order to respond to the modern problems and crises in Islamic societies. With a communicative approach, he believes in reconstruction of Islamic community through dialogue and communication within the public sphere. He also opposes the relegation of the religion to a set of regulatory, ethical, secular doctrines (Hafez, 2010: 35-36).

The Ennahdha Party (also known as Renaissance Party or simply Ennahdha) under the leadership of Rached Ghannouchi is the first Islamic party and movement that proposed the commitment to democracy as an Islamic necessity and also a religious priority in a quite clear and modernist manner (Sherif, 2011: 2). Ghannouchi's interpretation of democracy is in the form of a political system that derives its legitimacy from the people who are entitled to vote and choose their representatives. In this system, there are some mechanisms for the circulation of power, transformation of the government, accountability of government officials, etc. Using a field-oriented approach, Ghannouchi believes that, through the link between Islamic value system and moral code with democratic procedures, Islamic democracy model can terminate the decadence and tyranny in the Muslim world, and on the other hand, it can fulfill much of the promises violated by liberal democracies.

\subsection{Introducing Some Important Perspectives on Adaptation}

Esposito and Wall are two of the best and most equitable theorists in adaptation oriented approach that using jurisprudential, theoretical and referential citations advocate adaptability of Islam with democracy-albeit in a contextualized form and also challenge contrast approach. On the one hand, they believe that the modern age is the era of democracy and identity politics expansion, and thus democracy has become the dominant discourse today. On the other hand, in the Muslim world, Islamic revivalism, with an emphasis on religion and Islamic identity, has become a powerful force in all aspects of human life. Of course, demand for participation in democratic dynamics in Islamic and Arabic communities has also converted into an important reality (Esposito \& Wall, 2010: 39). Esposito is a thinker who regards democracy as a "governance manner" which can be 
implemented in multiple cultural-social environments in a localized and contextualized form. In the present global environment, limited and fanatical interpretation of some concepts such as democracy is highly dangerous and limited, even for deep-rooted democratic systems (Esposito \& Wall, 2010: 37).

They raised two important questions: a) in the theoretical realm, to what extent democratic capacities can be traced in jurisprudential and traditional sources in the Muslim world? B) To what extent contemporary Islamic movements are able to realize Islamic authenticity and democratic public participation effectively and simultaneously? (Esposito and Wall, 2010: 24). Using a positive and fair perspective, Esposito and Wall suggest that there is a high compatibility between Islam and democracy in religious modernism and moderate interpretation.

In the theoretical realm, some important principles such as Council, Ijam'e (consensus), and Ijtihad are some of the most important existing jurisprudential capacities in Islam that can be used to generate adaptability and compatibility between Islam and democracy. Making reference to the principle of tawhid (monotheism), Some Western theorists see an inherent conflict between Islam founded upon monotheistic and divine sovereignty, and democracy built upon human sovereignty and wisdom. With reliance upon monotheism, Mawdudi's as the leader of amaat-e-Islami (Ilsamic Nation) in Pakistan rejects human sovereignty. He underlines the fact that, in a political Islamic community, God is entitled to absolute sovereignty, yet God endowed man with Caliphate status to conduct the community within the framework of Islam Shari'a. He believes that the democracy must be organized into the category of monolithic worldview (Esposito \& Wall, 2010, 56). In this regard, democracy or pillar of the republican and democratic will proceeds alongside God's will. Thus, legislation and the content of decisions should not be in conflict with the text of the Quran and the Sunnah of the Prophet.

Within the framework of the "caliphate" principle, democracy is considered a mechanism for decision-making in the field of "the permissible" or "Manteqa al-Firaq" and also as a mechanism for the rulers, civil institutions and the public to be able to enforce rules and to be held accountable to such enforcement. According to the principle of Shura" (consultation), the theme of the caliphate of the Muslim public is raised, and since all Muslims are adult, wise, pious and caliph of God, they temporarily delegate their authority to a ruler that manages and monitors the society based on the principles including justice, Quran, Sunnah, reason and logic in the framework of Islamic democracy and on behalf of the general Caliphate. Ijmae or consensus as one of the legal sources of Sunni Muslims is meant to be Muslim's collective judgment on the issues raised, and it is consistent with the principle of referendum and public participation. In practice, in the history of Islam, the general consensus did emerge in the form of the council for the conclusion or termination of contract or the one composed of religious specialists. The concept of Ijame could provide the basis for the acknowledgement of majority, and the extent of the legitimacy of a government depends on the reflection of decision makings on the basis of Islam, justice, and the Muslim's demands, and public conformity to supervising rules and regulations (Esposito and Wall, 2010: 66).

According to Wall and Esposito, in practice, during two past decades, moderate Islamists have proved that when they are given the opportunity to participate, they do not exceed the democratic framework. The most evident example in this regard is Islamist AKP party (The Justice and Development Party, abbreviated JDP or AKP) in Turkey in the last two decades.

In many Muslim societies, the belief underlying the majority of Islamic spectra is that Islam is capable of the continuous re-organization of the society and the government with reliance upon the principle of Ijtihad, and some notions such as Shoura (Consultation), Ijmae (consensus) and paying attention to public interests and welfare are the basis for the compatibility between Islam and democracy, and improve modern Islamic beliefs or authentic democracy versions (Esposito, 2007: 71).

According to Esposito, serious obstacles to the establishment of democracy in Islamic countries are concerned with the nature of Islamic states. Although some of the governments take advantage of parliament and law and a democratic façade, the democratic institutions lack any real functioning because of the state authority and influence (Esposito, 2007: 70). While rejecting radical Islamists, authoritarian regimes have prevented modernist and moderate Islamists from any type of participation. However, on the other side of the world, in secular states such as Malaysia, Turkey, Chad, Bangladesh, Indonesia and Nigeria, and the Islamic states such as Jordan, Kuwait and Pakistan, Islamists have been allowed to participate. Even in a country like Turkey with its secular Constitution, The Justice and Development Party (abbreviated JDP or AKP) came to power, and it has been nowadays a model of political struggle for Islamists in some countries (Esposito and Wall, 2010: 28-27)

\section{Edward Said}

Edward Said is one of the most important Islamic scholars and defenders of Islam and compatibility between democracy and Islam. By introducing "Inverted Orientalism" theory, Said have sought to provide a serious 
response to the biased and anti-Islamic criticism proposed in the West. In this regard, he composed the valuable book "Orientalism" at late 1960s. Said's overall view is that the West has created an Orient that mainly has a discursive nature rather than a real nature, and the discursive nature has been largely manifested in the dialogue called "Orientalism", which itself is a part of the meta-discourse of the modernity in the West.

By creating Orientalist discourse, the West seeks to redefine itself, and to generate an "Other" through the establishment of relationship between knowledge and power. In such discourse in discussing the Orient, the Orient in general is absent, and the result of this "Western Orientalism" is to ignore the reality of the Orient and its people (Said, 1998, b: 374). Said's analysis revolves around the notion that the concept of Orientalism in fact had been and is a product of the West's discourse, a means of its cultural self-recognition, yet a tool to justify imperial control on the Oriental nations. Such Orientalism is paternalistic, self- centered, racist, and imperialist. Said's presupposition underlying the Orientalism is that, under the patronage and participation of colonialism and imperialism, the discourse of Orientalism has been able to deprive the Orient and Islamic countries of the international scene. A power-oriented relation is the most important part of this discourse that conceives the West as powerful, and the East as weak (Azdanlo, 1993: 17).

In Orientalism discourse, Islam should be manifested as an enemy and adversary to Christianity and Judaism. According to Said, at least from the eighteenth century onwards, the West's reaction to Islam is under the subjugation of a simplified ideology that is still continuing, and it is believed that Islam is a fundamentally opposed and hateful, violent and anti-democratic phenomenon. This simplified picture is influenced by three main reasons: 1-The conflict with Islam and Arab that is reflected in the West's Orientalism; 2-Israeli Zionism-Arab conflict and its impact on Jews in America and also on the liberal culture and the public; 3-Relative absence of any cultural situation and context through which can keep pace with the Arabs and Islam, or to discuss them without sensing any negative emotion (Said, 1998, a: 55).

Concerning the Orientalist discourse propagated in the West, Said puts emphasis on the function of the three powers Great Britain, France and most recently the United States. An important goal of Orientalist discourse is exclusion of Islam and preserving the cultural, political and economic hegemonic power of the West and the United States. Said states that full-electronic and Post-modern twentieth-century America significantly contributes to the presentation of a negative, violent and anti-democratic image of the Arabs, and such an image is largely influenced by the Arab-Israeli conflict. The relevant discourse is strongly advocated and promoted by the media and public discourse in the West (Singh \& Johnson, 2004: 54) To be more exact, since the Second World War onwards, following any of the Arab-Israeli conflicts, Arab Muslims have been introduced as one of the most hated and violent figures in US's popular culture and also in the academic, policymaking, and business world (Said, 1997: 159). Said makes impression that "Historically, we have been witness to Arabs as discarded and obedient people or racist in classical imperialism (Said, 1998, a: 162).

According to Shirin Hunter, Islamism in the Middle East is both influenced by the ideological commitment of the people to Islam and the result of specific political, economic, cultural and international conditions. Therefore, Islamist movements do not take the same stance toward the West and democracy (Hunter, 2004:145). In reviewing Islamism, Hunter analyzes the issue from a responsive (reactive) perspective, and regards Islamism phenomenon as the result of some factors including the hegemonic actions taken by the West against the Arab and Islamic countries, Islamic societies' concern with the cultural hegemony of the West, the secular governments' failure to establish social and economic justice in past decades, the West's protection of corrupt and repressive Arab regimes, and US and West's support from Israeli (Hunter, 2002: 157-165).

Hunter believes that the Clash of Civilizations and contrasts' approaches based on Islam's inherent contrast with West and democracy are not close to reality. From Hunter's perspective, if the conception of democracy is secular, there is an inherent incompatibility between Islam and democracy, but if the democracy is a governmental and non-secular trend and mixed with religion and local conditions, Islam is compatible with democracy (Hunter, 1381: 166). Hunter resists against Islamic scholars who believe that Islam has an inherent contrast with modernism and democracy, and categorizes them under the heading "cultural determinists" (Hunter, 2001: 95). He considers Islamic resurgence mainly due to the policies adopted by the West rather than the inherent contrast between Islam and the West. Despite the contrast and the hate form hegemonic policies of the West, a considerable part of Islamism lack problems and conflicts with democracy -of course, in a non-secular from and consistent with the principles of Islam (Hunter, 2001: 17).

\section{Hossein Nasr}

Hossein Nasr is a prominent scholar in Iran and the Muslim world. After the $11^{\text {th }}$ September Attacks, widespread and serious propaganda was targeted against Islam and Muslims, and Islamic thought was introduced as a violent 
and extremist ideology. Influenced by such humiliation and insult, Nasr committed himself to eliciting overwhelming responses to the West's polemical attacks. The current article does not seek to analyze all of his ideological aspects and mainly intends to underline his notions on the distinction between Islam and democracy.

In order to advocate Islam and to criticize the contrast, Nasr believes that if we make a distinction between radical Islam and moderate Islam, we come to the realization that overall interpretation presented by contrasts and theorists regarding Clash of Civilizations and Islam is wrong and misleading in general. According to Nasr, it is not realistic to neglect the genuine Islamic principles and deem them as equal with what has happened in the history under the guise of Islam, and to present historical evidence to insinuate the idea that Islam is a violent and anti-democratic religion.

Hossein Nasr regards the relationship between Islam and religious minorities in the Muslim world in Egypt, Iran and Turkey, in India, Nepal, Malaysia, Indonesia and Bangladesh as a human relationship in which Muslims have always lived peacefully with Buddhists, Christians and Hindus, and these peaceful relations have never caused violence, except when the Western foreigners have tarnished the situation and demolished peaceful relations. Whenever politically sensitive issue such as the partition of Palestine or India has demolished the normal relations between Muslims and followers of other religions, this coexistence is turned to violence. The tension and violence that can destroy the peaceful coexistence of religious minorities arises from the activities of Christian missionaries who have served colonialism and imperialism (Nasr, 2007: 64).

\section{Mansour Mo'addel}

From Mo'addel perspective, $19^{\text {th }}$ century secular legacy of modern life and modernity in the Colonial Era led to the emergence of the conflicts between Islam and rational-democratic government and modernity in the 20th century (Mo'addel, 2007: 48). Secular intellectual leaders in Islam and Arab world composed some books and treatises to attack the Islamic ideological system during the 20th century, which revolved around the inadequacy of Islamic government theory,

irrationality of religious rituals, antiquated training procedures and educational content in Islamic societies and the lack of compatibility between Islam and democracy (Mo'addel, 2007, 963). Mo'addel believes that a significant part of these comments that are built upon the conflict between Islam and rationality, modernity and democracy emanate from the twentieth century's dominant ideology of secularism in the Arab world that has profoundly influenced the relevant notions and theories.

To advocate Adaptation, Mo'addel states that it is unrealistic to overlook Islamic original fundamentals such as Ijame, Ijtehad, Shoura (Consultation) in connection with an analysis of the compatibility between democracy and Islam, and to attribute the function of authoritarian and autocratic states in the Arab and Muslim world to Islam. On the other hand, Mo'addel believes that in Arab and Islamic world, the fundamentalism as an anti-intellectual and anti-democratic mainstream do not represent merely the existing spectrum, thus Islamic modernist and revivalists that authenticate the compatibility of democracy and rationality with Islam are also actively involved. The notable point is that the emergence of Islamic anti-rational fundamentalism is a reaction to cultural invasion and economic and political domination of the West and has no connection with Islamic essence (Mo'addel, 2007: 49).

\section{Contrast and Essentialism Theories}

Contrasts are at completely opposite point from adaptation oriented party. In general, using a cultural approach, contrasts underline the substantial ontological difference between the West and Islam, thus believe in Islam's absolute incompatibility with democracy. In this section, the views held by the most important mainstreams in the area of Contrast are expressed.

\subsection{Islamic Traditionalist and Conservative Mainstream}

Historically, religious traditionalism mainstream was dominant in the Middle East until the mid-nineteenth century, and nowadays, traditional Salafists in a number of countries in the region, especially in Saudi Arabia, are prominent representatives of the current. Theoretically, this current believes in return to Islam, the provisions of the Qur'an and the Sunnah of the Prophet, and practically, the mainstream underlines monitoring and consultative mission of the government through a conservative and peaceful policy. They believe in perfect expression of the Quran and Sunnah of the Prophet and the Rashedin caliphs, and oppose any kind of experimentation and transformation within the framework of the principles of religion, traditions and social order in Muslim societies. The traditionalists are predominantly conservative, literalist, narrative-based (naql-gera), and also anti-rationalist. They are opposed to any kind of critical and liberal thinking, and rational debate on religion and traditions, and consider and denounce such practice as heresy. Contrary to Islamic modernists or 
moderates, they do not believe in Islam's compatibility with democracy and democratic and modern values (Sardarnia, 2012: 188-189).

Since the second half of the twentieth century, some reasons including evolution of generation, hasty modernization and innovation, the revolution of information and communication, propagation of democracy and relevant issues created a situation in which traditionalist and conservative religious mainstream lost its prominence, and different spectra emerged out of it. In this connection, new traditionalists or revivalists can be referred to. Although they seriously believe in the enforcement of Islamic principles and traditions, they (unlike traditional conservatives) somehow acknowledge limited choice of cultural and moral values of the West. Furthermore, they also advocate the use of the western technology in case of compatibility with Islam (Anderson, 2001: 154). However, conservative Salafi traditionalists underline the adequacy of Islam and traditions, the necessity to enforce them accurately, and contrast to any experimentation on governance including democracy and use of modern technologies (Scott, 2005: 162)

\subsection{Extremist Fundamentalist Stream}

Nowadays, this current is the prominent representative of contrast to rationalism, modernism and democracy in a situation-oriented form in the Arab and Muslim world. This interpretation of Islam following the failure of secular governments in Arab world turned into the dominant discourse in 1970s and 1980s, yet since the mid-1990s onwards, it lost its significance and prominence. Thus, religious modernists achieved too much influence and prominence in a considerable part of the Arab and Muslim world. The emergence and spread of blind violence by appalling fundamentalist groups such as Taliban, al-Ghaida, and al-Nusra, and more dangerous than all the "ISIS" in the contemporary era is a fatal blow to the fundamentalist discourse in the public opinion in the Arab and Muslim world.

In terms of doctrine and creed, radical fundamentalists are not different from Salafi traditionalists, they are considered Salafi, with the difference that do not have conservative orientation, and believe in the implementation of Islamic principles and establishment of an Islamic state through violent unrelenting jihad and fighting. Thus, unlike conservative traditionalists, they do not restrict their mission to mere monitoring of government and ethical recommendations along with political ambition. Radical fundamentalists consider Islamic resurrection as essential and inevitable panacea for ending the decline in communities, and consider Islam as a perfect religion and responsive to all human needs in terms of economic, cultural, political and military considerations (Sardarnia, 2013: 190).

Sayyid Qutb is recognized as the best leader and the father of radical fundamentalism, and the greatest ideologue, and most influential architect of radical Islam in the Middle East and North Africa. Based on Sayyid Qutb's opinions, the most important principles and directions of radical fundamentalists can be summarized as follows: 1-Islam constitutes the cultural, social and political essence and the spirit of the Muslims, 2-Islam is the only genuine form of governance, the rule of God on land, 3-The world is divided into two camps including Dar Al-Iman (household of faith) and Dar Al-Kofr (household of blasphemy), 4-The only resurrecting solution to redeem from degeneration and to achieve independence and self-guidance is the Holy Quran, behavioral approaches and Sunnah of the Prophet and Rashedin caliphs with a meta-historical perspective, 5-Innovation, Ijtihad, and modern and rational interpretations of religion and democracy are considered heretical and anti-religious experimentations, and 6- Defend the principle of Jihad to enable Dar Al-Iman to demolish Dar Al-Kofr (household of blasphemy), and broadening of the territorial and ideological space of Dar Al-Iman (Srdarnya, 2013: 191).

Sayyid Qutb attacks the entire principles underlying secular and humanist governance including democracy, and states that the Western democracies and world order suffer from total moral and spiritual decadence and decline. The only way out of the decadence is the recourse to the rule of Islam and monotheism and redemption from fake regimes under the guise of democracy and total sovereignty of Dar al-Iman over Dar al-Kufr. He categorizes democracy within the framework of Dar al-Kufr that lacks any adaptation and compatibility with Islamic state in terms of ontological and epistemological issues. He invites Muslims to universal jihad against the infidels and corrupt rulers and Western democracies (Calvert, 2004: 32).

Nowadays, al-Qaida and the Taliban and ISIS are the most important organizational representatives and parties affiliated with this anti-rational mainstream and serious opponents to democracy and religious modernity. Using a selective interpretation of the Qur'an, and through armed, bloody suicidal procedures, these groups fulfill their fundamentalist rhetoric, which are a disgrace to the Muslim world. Imen Zawahiri as the big former ideologue of jihad and the number two of Al-Qaeda believed that, based on the guiding principle of Tawhid (Monotheism), God Almighty is the mere true and just legislator in the world, and democracy due to the usurp of God's right to 
legislation is a type of profanity, and is doomed to failure. Any parliamentary participation and cooperation with the trappings of pseudo-democracy in seemingly Islamic regimes and theoretical attempt made by religious modernists in order to adapt democracy with Islam is unlawful and contrary to Islam, and the people are apostates and infidels. Democracy is a false slogan that advocates the rule of money and power rather than the true sovereignty of the majority. Public freedoms and the rule of the majority in this government system relegate human status to animal stage, propagates the sharp decline of ethical and moral principles, estrangement from transcendental divine values, and the spread of many taboos such as sex and nudity culture (Tamimi, 2007: 52).

In general, in this current of thought, the prevailing belief is that democracy is an alien concept and form of idolatry. Democracy is built upon a specific anthropological and humanistic foundation that is fundamentally incompatible and inconsistent with the principles of Islam and the Quran. Therefore, the compatibility between Islam and democracy is impossible. In addition, the establishment of a government that both is committed to Sharia and Islamic teachings and to democracy at the same time is a paradoxical thesis (Preacher, 2004: 222). Fundamentalists consider any endeavor to establish a link between Islam and democracy under the guise of religious democracy as doomed to failure. They regard democracy as a secular and decadent government policy and within the framework of humanism in lieu of God, because such governmental policy has some consequences such as estrangement from God, spirituality and moral values, war and violence, corruption, infidelity, extreme materialism, promiscuity, class conflict, discrimination. From the fundamentalists' view, democracy is the greatest threat to the Islamic faith (Tamimi, 2007: 51).

\subsection{Western Contrast Theorists}

David little proposes two basic presuppositions in connection with the contrasts. First, the religion is anti-modernity and -modernism and is the epitome of tradition, thus the religion and modern society are always incompatible. Second, based on the anti-modern character of the religion, any religious and political movement in modern society can find an anti-democratic nature (Ceske, 2010: 29-22).

In contrast approach and obstacles to democracy, "essentialism" is more prominent. The essentialist theorists put more emphasis on "culture" in relation to obstacles to democracy and the contrast between religious communities and democracy. They consider culture as a crucial, ancient, and profound element that is deeply rooted in the social structure of the society and history. In the meantime, there is a highly strong relationship between the culture and religion. With a bit of difference, "contextualists" underline the role of subcultures in connection with the distinction and contrast between traditional and modern societies, (Brynen, 2010: 3-4).

In general, from a predominantly essentialist and somehow contexualist perspective, contrasts analysts allege that there is an essential and inevitable enmity between Islamic civilization and the West. There is an inherent and fundamental incompatibility between Islam and the West in terms of ontology and epistemology, and the conflict cannot be resolved. After the September 11 attacks, the approach draw more charm and attention (Sardarnya, 2013: 214).

\section{Elie Kedourie}

Kedourie is one of the first theorists and Orientalists in contrast approach. From the perspective of essentialism and contextualism, he observes a serious contrast between Islam and the West and Western democracy. As an essentialist, he believes that Western democracy with fundamental principles such as human sovereignty, liberty, the rule of humanitarian law, pluralism, etc. is incompatible to Islamic worldview and tradition propagating some principles including divine sovereignty, belief in forgery and nullity of human sovereignty and traditions (Kedourie, 1994: 5-6). Elie Kedourie as an English historian states that "there is nothing in the political traditions of the Arab world that can be deemed compatible with the organizing conceptions of constitutional government and can make possible understanding of these conceptions" (Diamond, 2010).

From a contexualist perspective and historical approach, Kodourie believes that, because of deep-rooted tradition of Oriental despotism and sub-cultures and long-lasting pre-existing political and social authoritarianism and also the issue of religion, Arabic and Islamic communities are in serious confrontation with democracy. Thus, we fail to be hopeful of the long term realization of democracy in these communities (Kamrava, 2007: 191).

By combining contextualism and essentialism, Elie believes that the Arabic and Islamic societies and Islamic worldview with their unique ontological fundamentals are essentially unreformable. Thus, within the framework of epistemological fundamentals, it would not possible to create some changes to make Islam and democracy compatible (Hinnebusch, 2006: 376). In addition, the presence of tribalism culture and traditions, authoritarianism and deep-rootedness of elusive and primitive norms and values have hindered the compatibility between Arabic-Islamic communities and democracy. 
Rafael Patay, same as Elie Kodourie, in the book "Arab Mind" has used an essentialist and contexualist approach and psychological approaches, and believes that the mentality and psychology of the Arab people within a social, religious and cultural context in which it has been grown up and institutionalized is basically alien to democracy (Brynen, 2010: 4).

Using a non-realistic and people-centered Orientalism, Elie Kodorie introduces Islamic world as most important source of terrorism and violence, and believes that no re-writing is necessary any longer to introduce Arabic-Islamic world and the Muslims as the symbol of violence in modern time. There are especially Islamist groups who exploit religion to justify political violence (Kedourie, 1987: 12). In the area of the genealogy of political assassinations in Islam, Kedouries believes in the long history of terror in Islam. He makes reference to the martyrdom of Imam Ali (AS) and assassination of Hassan Sabah in the 11th and 12th centuries as the most famous theoretical and practical examples of the assassination, and traces down the history of the terrors to the present-time fundamentalist groups (Kavoosi, 2004: 136)

\section{Bernard Lewis}

Lewis is one of the most important theorists practicing in the area of contrast approach and of civilizational conflict between Islam and the West. As an essentialist thinker, he believes that in the Muslim world, religion and tradition with its anti-rationality, transmitted, and traditional fundamentals operates as an organizing principle, thus religious society depicted in this ideology is totally incompatible with rational, modern society and modernity (Kamrava, 2007: 192). Accordingly, contrast approach places itself under the category of essentialism, and alleges that there is an inherent incompatibility between Islam and democracy, thus political Islamists cannot even behave democratically. He is of the opinion that due to the rejection of modernity and human reason, in the Arabic and Islamic Middle East, the nation is not defined as the basic unit of human organization, and instead the nation is subjugated to religious authority. In his article "Islam and Liberal Democracy", Lewis makes reference to the incompatibility between Islamic teachings with liberal democracy and democratic systems, and introduces the only proper government for Islamic world as theocracy (Lewis, 1993: 96). From Lewis's perspective, in the past few centuries, with such epistemological and ontological sources, the Islamic world has sought to indoctrinate a denouncing representation of Europe and the Western democracies into the Muslim world, thus democracy has no place in these countries due to such negative and violent ideologies. According to Islamic perspective, "there is a long lasting and obligatory war between Islamic government and neighboring infidels, and it would be terminated only through the victory of Islam on the profanity and introduction of all of the people in the world into Dar al-Islam (Lewis, 2007: 315). From his perspective, Ottoman's great victory in the fifteenth and sixteenth century and the invasion of the Muslim armies on the Christendom greatly strengthened such medieval heritage beliefs (Lewis, 2007: 314).

Under such social and intellectual context, it was around the 19th and 20th century that, with a mixture of fear, humiliation, threats and ignorance, superiority and dominance of the West, the leaders of the Muslim world considered Western civilization and values of modern Western to be the biggest challenge to traditional ways of life and traditional notions (Kamrava. 2007: 192) Lewis believes that the end of the cold war made prominent the threat of Islam to the West and the belief in the necessity of creating a "overshadowed Other' in the West after the collapse of communism (Aydin \& Ozen, 2010: 546). The termination of the Cold War led to the perception in the West that the spread of political Islam is the initiation of a new cold war that puts the democratic West as a rival to the invasion of Islamic and religious fundamentalism of political Islam (Aydin \& Ozen, 2010: 546).

\section{Samuel Huntington}

Perhaps Samuel Huntington could be considered the most eminent thinker among contrasts and essentialist theorists. Huntington's views on the confrontation between Islam and the West and Western democracy are proposed under the heading of "The Clash of Civilizations". The conflict in the modern world is cultural-civilizational (rather than ideological-economic) built upon civilizational and cultural identity. This type of conflict is the last stage to the evolution of conflict in the modern world. Huntington alleges that cultural identity primarily emanates from religion, and considers both as the cornerstone of any civilization.

Numerating seven or eight civilization in the world, Huntington believes that a collision occurs between civilizations in the future, and bloodiest clash would ensue between the Islamic and Western civilizations. Thus, civilizational identity will become a central factor in determining the conflict and interactions (Huntington, 2008: 41-42). Islamists' encounter with the dominance of the Western dominion results from civilizational consciousness in Islamic world and the inherent conflict of the values relevant to this civilization and those of the secular culture of the West as a part of a war against the Western civilization (Huntington, 2008:45). Huntington clearly states that Islamic civilization is the greatest threat to world peace and democracy. Offering a 
series of specific data, he concludes that Muslims in the 1990s, more than any other civilization, have been involved in intergroup violence. According to T. R. Gur, Muslims were directly involved in 26 out of 50 clashes occurred in 1993 and 1994 (Huntington, 1996. P. 256-258).

Since the beginning of 1990s and the end of the Cold War, due to civilizational consciousness and the West's domination, Islamic threat has become the most serious threat to the West and Westerners. Huntington conceives Islam as an irrational, traditional, pre-modern, belligerent, and anti-secular monolithic threat against the West and as serious enemy of civilization and democracy in the West (Aidin \& Ozen, 2010: 548). With his essentialist and pessimist view, Huntington represents Islamic civilization and Islamist movements as homogenous, violent, anti-Western and anti-democratic. However, using the evidence and the criticisms leveled, in his last essay, Huntington modifies his theory to some extent, even though he does not leave aside whole of the main structure of his theories (Kamrava, 2007; 193).

From the perspective of an essentialist thinker, he believes that the main cause to the non-democratic nature of the Middle East is Islam, and Islam is a radical, anti-western and non-democratic religion, and comes to the conclusion that there is a strong correlation between the Western Christianity and democracy (Kamrava, 2007, p.19). He introduces Lebanon as the only Arab country that has experienced democracy. He adds the fact that, this democracy was also demolished when the Muslims became majority in this country (Huntington, 2007: 78).

\section{Francis Fukuyama}

Among contrast theorists, the most political person is Fukuyama. After the collapse of the Soviet Union, he proposed the thesis of "the end of history" based on the West's unchallenged supremacy and hegemony of liberal democracy. In his view, in the new era, we are living in the End of History, which means the triumph of Western ideas such as liberal democracy, western pluralism, and consumer society of worldwide homogeneous nation-states on the failure of communism and fascism and religious fundamentalism. In this view, the liberal democratic system is the final point of human ideological evolution and the final form of the government in human history. Accordingly, the globalization of liberal democracy can be considered the ultimate human destiny (Fuhuyama, 1989: 4). It is worth noting that thesis of "the End of History" is not merely a failure of communism ideology, rather it is the emergence of religious ideology and the ultimate triumph of secularism over religious rule. Thus, there is no room for democracy in a religious-Islamic form.

\section{Conclusion and Evaluation of the Two Theories}

An overall assessment indicates that, in contrast to contrast and Essentialism approaches, Adaptation approach is more tenable. However, although the approach is not free from shortcomings, its strengths overweigh the shortcomings. The most significant shortcoming of the approach is that, in spite of the belief in the compatibility between democracy and Islam and most significant democratic and intellectual potentials in Islam, the approach does not draw considerable attention to the nuances and differences between Islam and its relevant potentials and the western democracy. For example, this issue is somehow overlooked that whether we should deem democratic values and beliefs in Islam as absolute or relative or a combination of both? And if it is a combination of the two, the scales must weigh more in which direction? In this theoretical approach, a distinction has been made between the principle of Islam and its noble foundations with Islamic history and practice of governments. Furthermore, while the incompatibility between Islam from the view of traditionalists and radical fundamentalists with democracy as a bitter reality has been acknowledged, the dominant conviction is that the generalization of this radical mainstream to the entire Islam world in the West is totally biased and can be deemed as "totalitarian monopoly". To acknowledge the compatibility between democracy and Islam, the proponents of this approach use democracy as a governance manner, and make reference to the compatibility of Islamic fundamentals such as Shoura (Consultation), Ijmae, Ijteihad, etc. to democracy, and overlook the differences. In the meantime, considering generational, intellectual, and ideological realities, and the surveys conducted on the Middle East, they believe that the presence of a democracy compatible with Islam for the Middle East is inevitable.

Another arguments can be cited on tenability of this approach. In this approach, has been noticed to the current circumstances in the Islam world such as generational changes in youth, socio-political and cultural developments, and so on, and then, they believe that democracy is essential for the Muslim world. By attention to these circumstances, majority of Islamists adopt democratic approaches compatible with Islam, and they tend to be cooperative, peaceful and democratic. Adaptation-oriented parties advocate a "contextualized interpretation of democracy" namely localized modernity and democracy as a governance manner that adapting Islam and democracy, and apply principles such as Shoura (consultation) and Ijtihad (deducing conclusions through discretion). In this approach, there is a modern understanding of Islam while showing faithfulness to the original principles of Islam and to show existing adaptability between Islam and science, democracy, rationality and 
modern technology, through relying on Ijtihad and modern interpretations of the Holy QuranThey advocate adaptabity of Islam with formal democratic mechanisms such as free elections, the referendum, pluralism and the rule of the majority, and they defend from democratic principles and values such as freedom, the rule of law, leniency within the framework of the law and the principle of Ijtihad based on logical and rational interpretations Of religion and sacred texts, and they severely denounce violence. Meanwhile, the analysts in this approach realistically believe that the modern age is the era of democracy and identity politics expansion, and thus democracy has become the dominant discourse today. On the other hand, in the Muslim world, Islamic revivalism, with an emphasis on religion and Islamic identity, has become a powerful force in all aspects of human life.

In contrast, Contrast lacks a considerable tenability due to some reasons including in brief: failure to make a distinction between Islam and Islamic history and performance of seemingly Islamic and authoritarian governments, selective utilization and utilitarian monopoly of Islam, theological-jurisprudential performance and attitude of extremist fundamentalists and their blind violence and its extension to the whole of Islam and Islamic spectra, globalization of secular democracy liberal discourse and its combination with hegemonic ethnocentrism and supremacy of the West and fueling Islam phobia and defamation of the Islamic religion, the neglect to developed democratic attitudes in the Muslim world in recent decades, etc.

\section{References}

Anderson, R. et al. (2001). Politics and Change in the Middle East. Newjercy: Princeton Hall.

Aydin, M., \& Cinar, C. O. (2010). Civilizational Futures... Futures, 42.

Azdanloo, H. (1994). Basics of Orientalism Discourse. Political \& Economic Information Quarterly, 8(77-78).

Brynen, B. (2010). Political Culture and the Puzzle of Persistant Authoritarianism in the Middle East. In R. Prynen et al. (Eds.), Authoritarianism and Political Reform in the Arab World. UK: McGill University Press.

Calvert, J. (2004). The Mythic Foundations of Radical Islam, Orbis, winter.

Diamnond, L. (2010, January). Why There is no Arabic Democracy? Journal of Democracy, 21(1).

Esposito, J. (2007). Islam and Challenges to Democracy. Journal of Hamshahri's Kheradnameh, (20).

Esposito, J., \& Wall, J. (2010). Contemporary Islamic Movements: Islam and Democracy. Translated by Ahmad Shoja'eVand; ${ }^{\text {rd }}$ Ed. Teran; Nashr-e-Nai.

Fukuyama, F. (1989). The End of History. Retrieved from https://ps321.community.uaf.edu/files/2012/10/Fukuyama-End-of-history-article.pdf

Hafez, K. (2010). Radicalism and Political Reform in the Islamic and Western World. Cambridge: Cambridge University Press. https://doi.org/10.1017/CBO9780511778957

Haider, J. (1995). Political Islam is a Threat to the West. Greenharven Press.

Hinnebusch, R. (2006). Authoritarian Persistence, Democratization, theory of the Middle East. Democratization, 13(4). https://doi.org/10.1080/13510340600579243

Hunter, S. (2001). The Future of Islam-West Relations: Clash of Civilization or Peaceful Coexistence. Translated by Homayoun Majd, Tehran.

Hunter, S. (2002). Islamism: The Political Role of Islamist Movements in Contemporary Middle East. Translated by Parviz Karimi. Quarterly of Middle East Studies, (29).

Huntington, S. (2008). Chlleneges to Identity in America. Translated by Mohammad Reza Golshan Pajouh; Tehran: Abrar-e-Mo'aser Publications.

Kamrava, M. (2007). The Middle East democracy deficit in comparative Respective. Perspective on Global Development of Technology, 6. https://doi.org/10.1163/156914907X207720

Kavousi, L. (2004). Historical Restoration of Initial Stereotypical Perceptions: Major Perceptions on Muslim Outsiders. Translated by Karim H. Karim. Journal of Resaneh; Issue 57.

Kedourie, E. (1987). Ideas and anarchy in the Middle East. Encounter, 69(2), 58.

Kedourie, E. (1994). Democracy and Arab Political Culture. London, Frank Cass Press.

Lewis, B. (1993). Islam and Liberal Democracy. Atlantic Monthly, 271(2).

Mo'addel, M. (2007). Islam and Political Modernity: An Introduction to Historical Pathology of Culture and 
Politics in Islamic Countries. Translated by Seyed Jamal Kamali. Journal of Hamshahri's Kheradnameh, (2).

Moaddel, M. (2007). The Future of Islam After9/11. Futures, 36.

Nabavi, S. A. (2008). Political Islam in Middle East, A Transition to Moderation. In the Proceeding on Iran and Great Middle East; Tehran. R \& D Institute of Humanities.

Nasr, H. (2007). Beacon of Knowledge. Translated by Seyed Hasan Hosaini; Souroush Publications.

Said, E. (1998/A). Orientalism. Translated by Abdorahim Gavahi; Tehran: Nashr-e- Farhang Islami.

Said, E. (1998/B). The World, The Text, The Critic, and An Interview with the Author. Translated by Akbar Afsari; Tehran: Toos.

Sardarnia, K. (2013). An Introduction to Sociology in the Middle East. Tehran; Nashr-e-Mizan.

Scott, G. (2005). Islam and Islamic Extremism. Journal of Humanitistic Psychology, 45(2).

Sherif, A. (2011). Democratization of Islamic Movements in Egypt and Morocco, PH. D Dissertation in Political Sciences, Boston, Boston University Press.

Singh, A., \& Johnson, B. G. (2004). Interview with Edwars Said university. university press of Missisipi.

Tamimi, A. (2007). Islam \& Democracy Fromfrom Tahtavi to Ghannouchi. Theory, Culture \& Society, 24(2). https://doi.org/10.1177/0263276407074994

Timothy, D. S. (n.d.). Islam and Democracy. Translated by Sha'ebanAli Bahrampour and Hasan Mohaddesi; Tehran: Didgah Publications.

Vaezi, A. (2004). Religious Democracy and its Critics. Epistemic Studies in Islamic University.

\section{Copyrights}

Copyright for this article is retained by the author(s), with first publication rights granted to the journal.

This is an open-access article distributed under the terms and conditions of the Creative Commons Attribution license (http://creativecommons.org/licenses/by/4.0/). 